Article

\title{
Exopolysaccharides from the Energy Microalga Strain Botryococcus braunii: Purification, Characterization, and Antioxidant Activity
}

\author{
Wei-Nan Wang ${ }^{1,2,+}{ }^{\mathbb{D}}$, Tao Li ${ }^{1,3,+}$, Yi Li ${ }^{4}$, Ying Zhang ${ }^{4}$, Hua-Lian Wu ${ }^{1,3}$, Wen-Zhou Xiang ${ }^{1,3, *}$ and Ai-Fen Li ${ }^{4, *}$ \\ 1 CAS Key Laboratory of Tropical Marine Bio-resources and Ecology, Guangdong Key Laboratory of Marine \\ Materia Medica, Institution of South China Sea Ecology and Environmental Engineering, South China Sea \\ Institute of Oceanology, Chinese Academy of Sciences, Guangzhou 510301, China; \\ wangweinan0220@163.com (W.-N.W.); taoli@scsio.ac.cn (T.L.); hlwu@scsio.ac.cn (H.-L.W.) \\ 2 University of Chinese Academy of Sciences, Beijing 100049, China \\ 3 Southern Marine Science and Engineering Guangdong Laboratory (Guangzhou), Guangzhou 511458, China \\ 4 Engineering Research Center for Tropical and Subtropical Aquatic Ecological Engineering, Ministry of \\ Education, Jinan University, Guangzhou 510632, China; liyilbiology@163.com (Y.L.); \\ zhangying7005@163.com (Y.Z.) \\ * Correspondence: xwz@scsio.ac.cn (W.-Z.X.); tiger@jnu.edu.cn (A.-F.L.); Tel.: +86-20-89023223 (W.-Z.X.); \\ +86-20-85224366 (A.-F.L.) \\ + These authors contributed equally to this work.
}

\section{check for}

updates

Citation: Wang, W.-N.; Li, T.; Li, Y.; Zhang, Y.; Wu, H.-L.; Xiang, W.-Z.; Li, A.-F. Exopolysaccharides from the Energy Microalga Strain Botryococcus braunii: Purification, Characterization, and Antioxidant Activity. Foods 2022, 11, 110. https://doi.org/10.3390/ foods 11010110

Academic Editor: Francisco Javier Señoráns

Received: 21 November 2021 Accepted: 29 December 2021 Published: 1 January 2022

Publisher's Note: MDPI stays neutral with regard to jurisdictional claims in published maps and institutional affiliations.

Copyright: (C) 2022 by the authors. Licensee MDPI, Basel, Switzerland. This article is an open access article distributed under the terms and conditions of the Creative Commons Attribution (CC BY) license (https:// creativecommons.org/licenses/by/ $4.0 /)$.

\begin{abstract}
Botryococcus braunii, a prestigious energy microalga, has recently received widespread attention because it can secrete large amounts of exopolysaccharides (EPS) with potential applications in food, cosmetics, and nutraceuticals. Unfortunately, the insufficiency of research on the bioactivity and structure-activity relationship of B. braunii EPS has impeded the downstream applications. In the present study, alcohol precipitation, deproteinization, and DEAE-cellulose column chromatography were used to extract and purify B. braunii SCS-1905 EPS. It was found that B. braunii SCS-1905 EPS were high-molecular-weight heteropolysaccharides containing uronic acid (7.43-8.83\%), protein $(2.30-4.04 \%)$, and sulfate groups $(1.52-1.95 \%)$. Additionally, the EPS primarily comprised galactose $(52.34-54.12 \%)$, glucose (34.60-35.53\%), arabinose (9.41-10.32\%), and minor amounts of fucose $(1.80-1.99 \%)$, with the presence of a pyranose ring linked by a $\beta$-configurational glycosidic bond. Notably, the antioxidant activity of crude exopolysaccharides (CEPS) was stronger, and the half maximal inhibitory concentration $\left(\mathrm{IC}_{50}\right)$ for $\mathrm{ABTS}$ and hydroxyl radicals was significantly lower than that of deproteinized exopolysaccharides (DEPS). Overall, this study indicated a potential application of B. braunii SCS-1905 EPS as a natural antioxidant. In summary, B. braunii EPS could be used as a potential feedstock for the production of antioxidant health foods.
\end{abstract}

Keywords: Botryococcus braunii; L race; exopolysaccharides; chemical composition; antioxidant activity

\section{Introduction}

Exopolysaccharides (EPS), known as extracellular polymeric substances, are macromolecular mixtures of polysaccharides secreted by microalgae into the extracellular matrix during the life cycle [1]. Exopolysaccharides are ecologically essential, besides protecting cells from dehydration and toxic substances and acting as energy and carbon sinks in response to nutrient stresses [2]. They also contribute to promoting the formation of algal aggregates, mediate cell-matrix adhesion and play an important role in the stability of biofilm structure [3].

The potential for EPS to be used in a variety of industries, including food, medicine, cosmetics, manufacturing, etc. has made it economically appealing and is increasingly becoming a research hotspot for scientists. Microalgal EPS were first developed as thickeners and bio-lubricants in food products due to their unique physical properties such as high 
viscosity and excellent rheological properties [4,5]. The chemical composition and structural properties of polysaccharides can significantly affect the physicochemical properties and biological activities. Studies on the application of EPS are gradually diversifying as a growing number of species of microalgal EPS are identified. EPS, like biomass, has a high value for food production as a carbon pool. Microalgal polysaccharides or their derivatives contain soluble dietary fibers, which are not fermented, at least not completely, by colonic microbiota, can positively regulate the microbiota associated with obesity and diabetes in the human gut, playing a major role in human health and diseases [6].

Numerous studies have suggested that microalgal EPS possess various biological activities such as antioxidant, anti-inflammatory, antiviral, and antitumor properties, which is expected to be a potential feedstock for nutritional supplements, cosmetics, and pharmaceuticals. As by-products of the microalgae culture process, EPS can be dissolved in the culture medium, that makes the preparation process simpler compared to intracellular products and has more advantages for industrialization. For instance, Porphyridium cruentum EPS have antioxidant, antibacterial and antiviral properties; the carrageenan induced paw edema test revealed that EPS from Chlorella stigmatophora and Phaeodactylum tricornutum possess an anti-inflammatory ability; Aphanothece halophytica EPS (EPAH) was proven effective in the treatment of pneumonia caused by influenza virus A FM (H1N1) [7-10]. At present, microalgal EPS has been believed to have broad application prospects. Frutarom Industries Ltd. (Israel) has successfully extracted the EPS and converted it into cosmetics with large-scale cultivation. Admittedly, no other species of microalgal EPS have achieved commercial applications.

The unicellular colonial microalga B. braunii is a member of the Trebouxiophyceae (Chlorophyta) widespread in fresh and brackish waters of temperate and tropical zones [11]. $B$. braunii has been widely regarded as a promising source of sustainable bioenergy production due to its capability to produce large amounts of lipids and hydrocarbons (up to $86 \%$ of dry weight). According to the characteristic hydrocarbon they produce, B. braunii have been classified into four chemical races A, B, L, and S. Race A accumulates odd-numbered unbranched alkadienes and trienes (C23-C33); race $\mathrm{B}$ accumulates polymethylated triterpenes $\mathrm{C}_{\mathrm{n}} \mathrm{H}_{2 \mathrm{n} 10}$ (C30-C37), the botryococcenes [12]; race $\mathrm{L}$ is characterized by single tetraterpenoid hydrocarbon called lycopadiene [13], and race S produces hydrocarbon comprising epoxy-n-alkane and saturated n-alkane chains with carbon numbers 18 and 20 [14].

In addition to its excellent performance in the production of hydrocarbons and lipids, B. braunii can secrete large amounts of EPS, making it promising for commercial production and applications. Casadevall et al., (1985) observed a large amount of glycofibrils attached to algal cells through transmission electron microscopy for the first time [15]. A non-axenic strain of the microalga B. braunii UC 58, isolated from a small lake in Portugal by Fernandes et al., (1989), showed remarkably high quantities of EPS (up to $4.5 \mathrm{~g} \mathrm{~L}^{-1}$ ), which contained fucose and galactose in a proportion of 0.6:1 [16]. Allard and Casadevall (1990) studied the EPS of five strains of B. braunii from three different chemical races A, B, and L. Among them, the EPS production of A and B strains was about $0.25 \mathrm{~g} \mathrm{~L}^{-1}$, while the production of the L strain was up to $1.0 \mathrm{~g} \mathrm{~L}^{-1}$. Galactose accounted for the main part of B. braunii EPS [17]. So far, there have been large amounts of studies on influencing factors of EPS production and outdoor cultivation of B. braunii. However, there are few studies of the biological activity of $B$. braunii EPS. The biological activity of EPS deserves our attention and is an important theoretical foundation for commercial applications in the future.

In this study, the microalgae strain B. braunii SCS-1905 was newly isolated from a small lake in Guangdong Province, China, by the authors of this study. During the cultivation period, a large amount of uplifted foam and viscous texture appeared in the culture medium. After extraction, isolation, and purification of the medium, several different EPSs were obtained, including CEPS (crude exopolysaccharides), DEPS (deproteinized exopolysaccharides), and purified fractions of EPS-1, EPS-2, and EPS-3, and described in terms of chemistry and primary structure. In addition, antioxidant activities in vitro of 
the EPS were investigated to evaluate the commercial application potential as well as to explore the potential development and utilization.

\section{Materials and Methods}

\subsection{Microalgae and Culture Conditions}

B. braunii SCS-1905, isolated from a small lake on Panyu District in Guangzhou (Guangdong Province, China), was preserved in South China Sea Institute of Oceanology, Chinese Academy of Sciences (Guangzhou, China). It was inoculated in a glass column photobioreactor ( $\varnothing 6.0 \mathrm{~cm} \times 60 \mathrm{~cm}$ ) containing modified BG-11 medium (mBG-11) [18]. The culture period was 20 days. During this period, the strain was bubbled with $\mathrm{CO}_{2}-$ enriched compressed air $\left(1 \% \mathrm{CO}_{2}, v: v\right)$, filtered through a $0.2 \mu \mathrm{m}$ sterile disposable filter were provided with $200 \mu \mathrm{mol}$ photons $\cdot \mathrm{m}^{-2} \mathrm{~s}^{-1}$ one-side illumination by $\mathrm{T} 8$ fluorescent lamp (Philips, Eindhoven, The Netherlands) at $25 \pm 1{ }^{\circ} \mathrm{C}$.

\subsection{Morphological Observation and Phylogenetic Tree Construction}

Morphological characteristics of the cells were observed under an Olympus BX41 microscope (Olympus Corporation, Tokyo, Japan). The CTAB (conventional cetyltrimethylammonium bromide) method was used for DNA extraction as described by Chen et al., (2014) [19]. A (5'-CTGGTTGATCCTGCCAGT-3') and B (5'-CACCTACGCAAACCTTGTTACGACTT-3') were used as primers for the $18 \mathrm{~S}$ rRNA gene sequence. The $\mathrm{PCR}$ reaction was carried out using the KOD-Plus-Neo DNA polymerase (Toyobo, Osaka, Japan) according to the procedure described by Li et al., (2016) [18]. The PCR procedure include that: (1) pre-denaturation at $94{ }^{\circ} \mathrm{C}$ for $3 \mathrm{~min}$, (2) denaturation at $94^{\circ} \mathrm{C}$ for $15 \mathrm{~s}$, (3) annealing at $5^{\circ} \mathrm{C}$ for $30 \mathrm{~s},(4)$ extension at $68{ }^{\circ} \mathrm{C}$ for $7 \mathrm{~min}$, (5) the process was repeated for 30 cycles. DNA gel extraction kit (TIANGEN Biotech., Beijing, China) was used to recover and purify PCR results. The purified PCR result was sequenced. The phylogenetic tree was built using ClustalX 1.8 and MEGA 4.0 software.

\subsection{Preparation of Crude Exopolysaccharides (CEPS) and Deproteinized Exopolysaccharides(DEPS)}

The algae cells were separated by centrifugation at $3996 \times g$ for $5 \mathrm{~min}$, and the supernatant obtained was concentrated by a RE-2000A rotary evaporator (Yarong, Shanghai, China) at $50{ }^{\circ} \mathrm{C}$. Subsequently, the concentrated supernatant was dialyzed against distilled water to remove small molecules ( $1 \mathrm{kDa}$ cutoff). Finally, 95\% ethanol was added to the supernatant ( $95 \%$ ethanol: supernatant $=4: 1, v: v)$. The collected flocs were crude exopolysaccharides (CEPS).

The Sevag method was used to remove protein from CEPS [20]. Briefly, $3 \mathrm{~mL}$ CEPS solution and $1 \mathrm{~mL}$ of the chloroform: n-butanol solution (4:1, v:v) were added in a tube. After shaking vigorously for $30 \mathrm{~min}$, the aqueous phase and the organic phase were separated by centrifugation. Polysaccharides exist in the aqueous phase while denatured proteins exist in the organic phase. The polysaccharide solutions collected after each deproteinization were scanned for the full-wavelength spectrum using the UV (ultraviolet)visible spectrophotometer, and the absorbance at $280 \mathrm{~nm}$ was used as an indicator to determine the protein removal. The above operation was repeated 4-5 times, and then after alcohol precipitation and lyophilization, deproteinized exopolysaccharides (DEPS) were collected.

\subsection{Purification by Ion Exchange Chromatography of Exopolysaccharides (EPS)}

A cellulose DE-52 column (Ø26 mm $\times 0.3 \mathrm{~m}, 50 \mu \mathrm{m})$ (newprobe, Beijing, China) equilibrated with distilled water was used to fractionate the DEPS solution in distilled water. The DEPS was prepared as a $10 \mathrm{mg} \mathrm{mL}^{-1}$ polysaccharide solution that was added to the ion exchange column wall after it had been pre-equilibrated with distilled water. The column was eluted with distilled water, followed by $0.4,0.8$, and $2.0 \mathrm{~mol} \mathrm{~L}^{-1} \mathrm{NaCl}$ solution at $1 \mathrm{~mL} \mathrm{~min}^{-1}$ in order. The elution volume of each phase was $100,200,200$, and $100 \mathrm{~mL}$, respectively. In each tube, $10 \mathrm{~mL}$ aliquots were collected, and the carbohydrate content was determined using the phenol sulfuric acid method [21]. 


\subsection{Determination of EPS Composition}

Total carbohydrate content was determined by the phenol sulfuric acid method [20]. Protein content was determined by the Lowry method (Folin-phenol method), which is based on the biuret reaction by Oliver H. Lowry [21]. The peptide bond in the protein reacts with $\mathrm{Cu}^{2+}$ under alkaline conditions to form a protein- $\mathrm{Cu}^{2+}$ complex. Folin-phenol reagent can be reduced by this complex, and there is a linear relationship between the intensity of the blue color $(750 \mathrm{~nm})$ and the protein content. The uronic acid content was measured using a colorimetric method based on the meta-hydroxyphenyl reagent [22]. The sulfate content was calculated as reported by Reim (1991) [23]. With $2 \mathrm{~mL}$ of $1 \mathrm{~mol} \mathrm{~L}^{-1}$ hydrochloric acid, the EPS was hydrolyzed for $6 \mathrm{~h}$ at $100{ }^{\circ} \mathrm{C}$. After filtering with a 0.45 $\mu \mathrm{m}$ microporous membrane, the distilled water volume was increased to $5 \mathrm{~mL}$, and the sulfate content was measured using a DIONEX ICS-2500 ion chromatography (DIONEX, Sunnyvale, CA, USA).

The EPS and reference samples were derivatized according to the procedure described by Luo et al., (2010) [24]. The sample (5 mg) was dissolved in $2 \mathrm{~mL}$ of $2 \mathrm{M}$ trifluoroacetic acid solution to hydrolyze at $110{ }^{\circ} \mathrm{C}$ for $2 \mathrm{~h}$, and then repeatedly co-distilled with methanol to dryness. Hydroxylamine hydrochloride, inositol and pyridine were added to the sample hydrolysate and shaken at $90^{\circ} \mathrm{C}$ for $30 \mathrm{~min}$. Subsequently, acetic anhydride was added and shaking at $90{ }^{\circ} \mathrm{C}$ for $30 \mathrm{~min}$. After cooling, the aldonitrile acetate derivatives were obtained to analyze the monosaccharide composition of EPS. The monosaccharide components were determined by GC-2014 gas chromatograph (Shimadzu, Kyoto, Japan) equipped with a flame ionization detector and an SH-Rtx-5 capillary column $(30 \mathrm{~m} \times 0.25 \mathrm{~mm} \times 0.25 \mu \mathrm{m}$, Shimadzu, Kyoto, Japan). Argon was used as the carrier gas at a flow rate of $1 \mathrm{~mL} \mathrm{~min}^{-1}$. The temperature of the column was set to rise from $120^{\circ} \mathrm{C}$ (with $3 \mathrm{~min}$ hold) to $210^{\circ} \mathrm{C}$ in 3 min (with 4 min hold). The injection port and detector had temperatures of $250{ }^{\circ} \mathrm{C}$ and $280{ }^{\circ} \mathrm{C}$., respectively. The injection volume was $1.0 \mathrm{~L}$, with a 30: 1 split ratio.

\subsection{Fourier Transform Infrared Spectroscopy (FT-IR) Analysis}

$\mathrm{KBr}(200 \mathrm{mg}$ ) was added to the samples and KBr pellets were prepared for FT-IR analysis. The infrared spectrum of EPS $\left(400-4000 \mathrm{~cm}^{-1}\right)$ was examined with an IR affinity-1 Fourier transform infrared spectrometer (Shimadzu, Kyoto, Japan).

\subsection{In Vitro Antioxidant Activity Assay}

\subsubsection{ABTS (2,2'-Azinobis (3-Ethylbenzothiazoline-6-sulfonic Acid)) Radical-Scavenging Ability}

The scavenging ability of EPS and DEPS against 2,2'-Azinobis (3-ethylbenzothiazoline-6sulfonic acid) (ABTS) radicals was determined using the method described by Li et al., (2012) [25]. We mixed 7.4 mM ABTS diammonium salt and $2.6 \mathrm{mM}$ potassium persulfate $\left(\mathrm{K}_{2} \mathrm{~S}_{2} \mathrm{O}_{8}\right)$ in an equal volume and left in the dark for $12 \mathrm{~h}$. The mixture was diluted with phosphate buffer at $\mathrm{pH} 7.4$ to achieve an absorbance of $0.70 \pm 0.02$ at $734 \mathrm{~nm} .0 .8 \mathrm{~mL}$ ABTS free radical working solution was added to $0.2 \mathrm{~mL}$ of samples at 1.0, 2.0,3.0, 4.0, $5.0 \mathrm{mg} \mathrm{L}^{-1}$ concentrations, shaken and incubated at $37^{\circ} \mathrm{C}$ for $15 \mathrm{~min}$. Ascorbic acid was used as a positive control. The absorbance was determined at $734 \mathrm{~nm}$ at an Epoch ${ }^{\mathrm{TM}} 2$ Microplate Spectrophotometer (Bio-Tek Instruments, Winooski, USA). The following equation was used to calculate the ABTS radical-scavenging activity:

$$
\text { Scavenging capacity }(\%)=\left(\mathrm{OD}_{0}-\mathrm{OD}_{1}\right) / \mathrm{OD}_{0} \times 100
$$

where $\mathrm{OD}_{0}$ represents the absorbance of the control group (distilled water rather than the sample solution), and $\mathrm{OD}_{1}$ represents the absorbance of the experimental group.

\subsubsection{Hydroxyl Radical-Scavenging Ability}

Hydroxyl radical $(\cdot \mathrm{OH})$ scavenging activity was carried out according to Li's methods (2008) with minor modification [26]. Reaction mixture was prepared by addition of 0.1 $\mathrm{mL}$ of each reagent including $0.75 \mathrm{mM} \mathrm{1,10-phenanthroline,} 0.75 \mathrm{mM} \mathrm{FeSO}_{4}$, and $0.15 \mathrm{M}$ phosphate buffer (pH 7.4). $0.1 \mathrm{~mL}$ of sample at various concentrations (1.0, 2.0, 3.0, 4.0, 
$5.0 \mathrm{mg} \mathrm{L}^{-1}$ ) was added to the reaction mixture, with $0.01 \%$ of $\mathrm{H}_{2} \mathrm{O}_{2}$ added in the end. Ascorbic acid was applied as a positive control. The absorbance was measured at $536 \mathrm{~nm}$ after 30 min of shaking at $37^{\circ} \mathrm{C}$. The following equation was used to calculate the hydroxyl radical-scavenging activity:

$$
\text { Scavenging capacity }(\%)=\left(\left(\mathrm{OD}_{1}-\mathrm{OD}_{0}\right) /\left(\mathrm{OD}_{2}-\mathrm{OD}_{0}\right)\right) \times 100
$$

where $\mathrm{OD}_{0}$ represents the absorbance of the negative control group (distilled water rather than the sample solution), $\mathrm{OD}_{1}$ represents the absorbance of the experimental group, and $\mathrm{OD}_{2}$ represents the absorbance of the normal group (distilled water rather than hydrogen peroxide).

\subsubsection{DPPH (2,2-Diphenyl-1-picrylhydrazyl) Radical-Scavenging Ability}

The DPPH radical scavenging activity was measured following the methods reported by Chen et al., (2018) [27]. In an equivalent amount of $0.1 \mu \mathrm{M}$ DPPH ethanol solution, samples of various concentration $\left(0.2,0.4,0.6,0.8\right.$, and $\left.1.0 \mathrm{mg} \mathrm{L}^{-1}\right)$ were added. Ascorbic acid was used as a positive control. After $30 \mathrm{~min}$ of dark reaction at room temperature $\left(25^{\circ} \mathrm{C}\right)$, the absorbance was measured at $517 \mathrm{~nm}$. The following equation was used to calculate the DPPH radical-scavenging activity:

$$
\text { Scavenging capacity }(\%)=\left(1-\left(\mathrm{OD}_{1}-\mathrm{OD}_{2}\right) / \mathrm{OD}_{0}\right) \times 100
$$

where $\mathrm{OD}_{0}$ is the absorbance of the control group (distilled water rather than the sample solution); $\mathrm{OD}_{1}$ is the absorbance of the experimental group; $\mathrm{OD}_{2}$ is the absorbance of the blank group (ethanol rather than DPPH).

\subsubsection{Superoxide Anion Radical-Scavenging Ability}

The superoxide anion free radical test kit (Jiancheng, Nanjing, China) was used to determine the superoxide anion scavenging activity of the sample (1.0, 2.0, 3.0, 4.0, $5.0 \mathrm{mg}$ $\mathrm{L}^{-1}$ ), which is based on simulating the reaction system of xanthine and xanthine oxygenase in the body. Ascorbic acid was used as a positive control. The following equation was used to calculate the DPPH radical-scavenging activity:

$$
\text { Scavenging capacity }(\%)=\left(1-\left(\mathrm{OD}_{1} / \mathrm{OD}_{0}\right)\right) \times 100
$$

where $\mathrm{OD}_{0}$ is the absorbance of the control group (distilled water rather than the sample solution), $\mathrm{OD}_{1}$ is the absorbance of the experimental group.

\subsection{Statistical Analysis}

All assays were repeated with three independent biological replicates and three technical replicates. The SPSS 18.0 was used for one-way analysis of variance (ANOVA) with subsequent post hoc multiple-comparison LSD tests. The $\mathrm{IC}_{50}$ (half maximal inhibitory concentration) was determined using GraphPad Prism 7 to characterize the effective concentration of EPS when the scavenging activity of free radicals in the system reaches $50 \%$. The results were considered significant at differences of $p<0.05$ and represented as mean \pm standard deviations error of mean.

\section{Results}

\subsection{Morphological and Molecular Identification of Microalgal Strain}

The single cells were oval in shape and covered on the top of the irregularly branched, translucent glue colony, as seen under optical microscopy $(\times 400)$ (Figure 1a,b). In addition, the cell had a yellow-green pigment body that is cup-shaped or leaf-shaped. With a population diameter of 40-70 $\mu \mathrm{m}$, single cells were 3-6 $\mu \mathrm{m}$ in width and 6-12 $\mu \mathrm{m}$ in length. The morphology characteristics of strain SCS-1905 conformed to B. braunii species. 

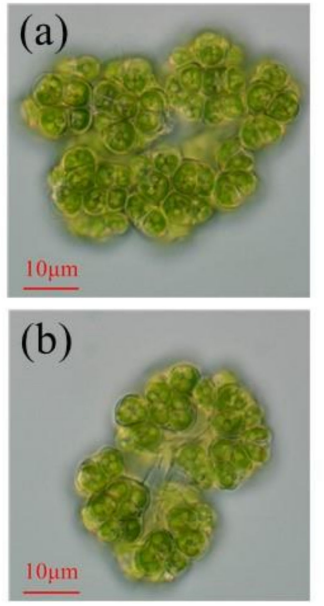

(c)

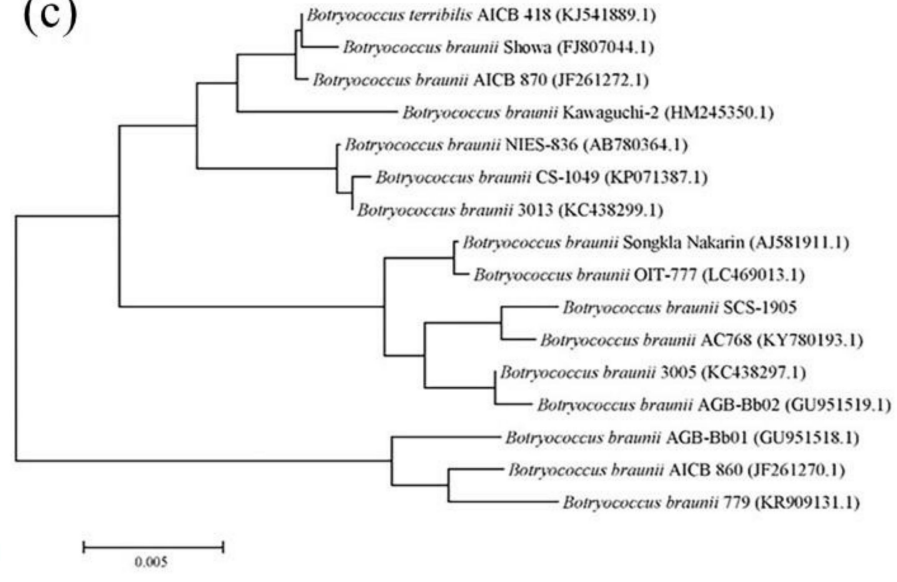

Figure 1. Cell morphology of Botryococcus braunii SCS-1905 (a,b) and the phylogenetic tree based on 18S rRNA gene sequence of Botryococcus braunii species using the neighbor-joining method (c).

Total base pairs of $18 \mathrm{~S}$ rRNA gene of SCS-1905 were obtained by sequencing. BLAST analysis revealed that strain was closely related to B. braunii AC768 (99.9\%) (Figure 1c). Based on the morphological and molecular analyses, it was preliminarily concluded that the microalgal strain SCS-1905 belonged to Chlorophyta, Trebouxiophyceae, Trebouxiales, Botryococcaceae, and Botryococcus braunii.

\subsection{Preparation and Chemical Composition of EPS}

The extraction and purification for B. braunii SCS-1905 EPS followed the procedure outlined in Figure 2. During the growth process of B. braunii SCS-1905, a large amount of white foam was investigated in the upper layer of the culture (Figure 2a). After the addition of $95 \%$ ethanol to the supernatant, large amounts of floating flocculent appeared (Figure $2 b$ ). CEPS was extracted from the culture adopting 95\% ethanol precipitation, dialysis desalination, and lyophilization. DEPS was obtained after deproteinization using the Sevag method, and EPS purification was performed using the DEAE-cellulose column. The desalted and freeze-drying CEPS was a yellow powder and had no obvious odor (Figure 2c). Compared with CEPS, the flocculent DEPS was white in color and had higher solubility (Figure 2d). In the end, three kinds of novel exopolysaccharides termed EPS-1, EPS-2, and EPS-3 were isolated, with a total recovery of $40.53 \%$ after purification from DEPS.

The absorption spectrum of CEPS solutions was determined during the deproteinized process (Figure 3). The presence of aromatic amino acids with conjugated double bonds in proteins displayed a distinct corresponding UV peak with an absorption maximum at $280 \mathrm{~nm}$, thus the presence of proteins in the sample can be determined by a UV-visible spectrophotometer. As deproteinization proceeded sequentially, the protein content decreased sequentially in the samples compared to CEPS. Deproteinization was repeated four times, the scanning curve was virtually flat, and the samples were collected after the fourth deproteinization, named DEPS.

The properties of CEPS and DEPS, including carbohydrate, protein, uronic acid, and $\mathrm{SO}_{4}{ }^{2-}$ contents, are summarized in Table 1 . The preliminary chemical composition results showed that the total carbohydrate, protein, uronic acid, and $\mathrm{SO}_{4}{ }^{2-}$ contents of CEPS were $42.39 \%, 4.04 \%, 7.43 \%$, and $1.95 \%$, respectively. While the preliminary chemical composition of DEPS was significantly different from CEPS, the total carbohydrate of DEPS was increased to $58.88 \% \mathrm{DW}$, an increase of $38.90 \%$, and the uronic acid content was increased to $8.83 \% \mathrm{DW}$, an increase of $18.84 \%$. The sulfuric acid content was reduced to $1.52 \% \mathrm{DW}$, which was a reduction of $22.05 \%$, and the protein content was reduced to $2.3 \% \mathrm{DW}$, which was a reduction of $43.06 \%$. 

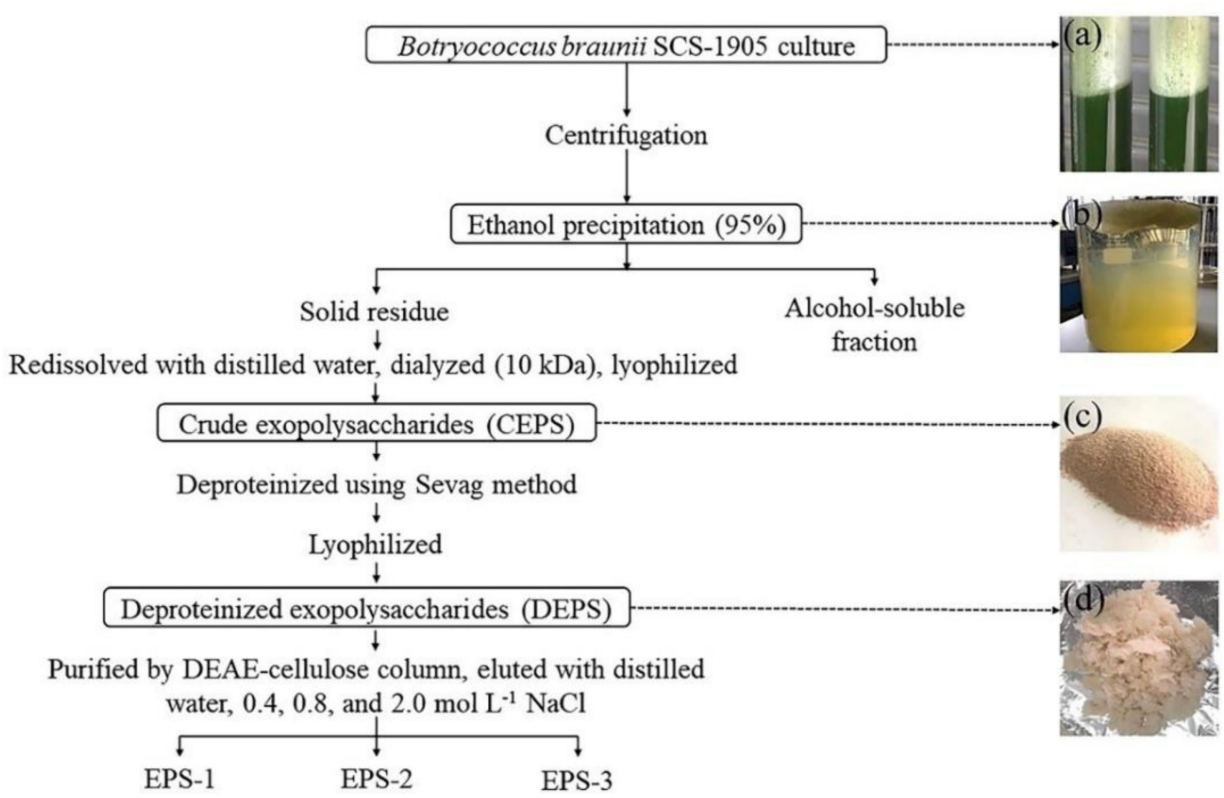

Figure 2. The extraction and purification procedure of exopolysaccharides. (a) culture, (b) ethanol precipitation, (c) crude exopolysaccharides (CEPS), and (d) deproteinized exopolysaccharides (DEPS).

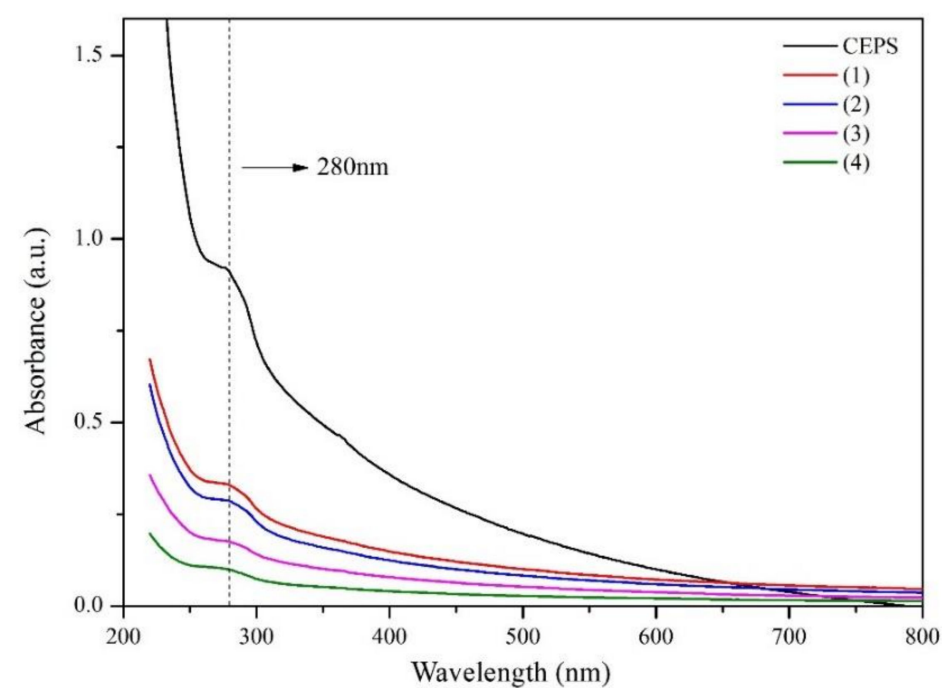

Figure 3. Absorption spectrum of exopolysaccharides. CEPS: crude exopolysaccharides, (1) first deproteinized procedure, (2) second deproteinized procedure, (3) third deproteinized procedure, (4) fourth deproteinized procedure.

Table 1. Chemical composition of exopolysaccharides.

\begin{tabular}{ccc}
\hline \multirow{2}{*}{ Chemical Composition (\%DW) } & \multicolumn{2}{c}{ Sample } \\
\cline { 2 - 3 } & CEPS & DEPS \\
\hline Total carbohydrate & $42.39 \pm 0.15$ & $58.88 \pm 1.23$ \\
Protein & $4.04 \pm 0.14$ & $2.30 \pm 0.08$ \\
Uronic acid & $7.43 \pm 0.47$ & $8.83 \pm 0.99$ \\
Sulfate & $1.95 \pm 0.01$ & $1.52 \pm 0.04$ \\
\hline
\end{tabular}

DW: dry weight, CEPS: crude exopolysaccharides, DEPS: deproteinized exopolysaccharides $(n=3$; data: mean $\pm \mathrm{SD})$. 


\subsection{Purification and Chemical Composition of Purified Fractions}

By eluting with different concentrations of $\mathrm{NaCl}$ solution, three fractions were collected, namely EPS-1 (eluted with $0.4 \mathrm{M} \mathrm{NaCl}$ solution), EPS-2 (eluted with $0.8 \mathrm{M} \mathrm{NaCl}$ solution), and EPS-3 (eluted with $2.0 \mathrm{M} \mathrm{NaCl}$ solution). According to the elution peaks, the fractions were merged in order. The polysaccharide samples were obtained after ethanol precipitation, dialysis, and lyophilization, which accounted for $54.06 \%, 23.24 \%$, and $22.70 \%$, respectively (Figure 4 ).

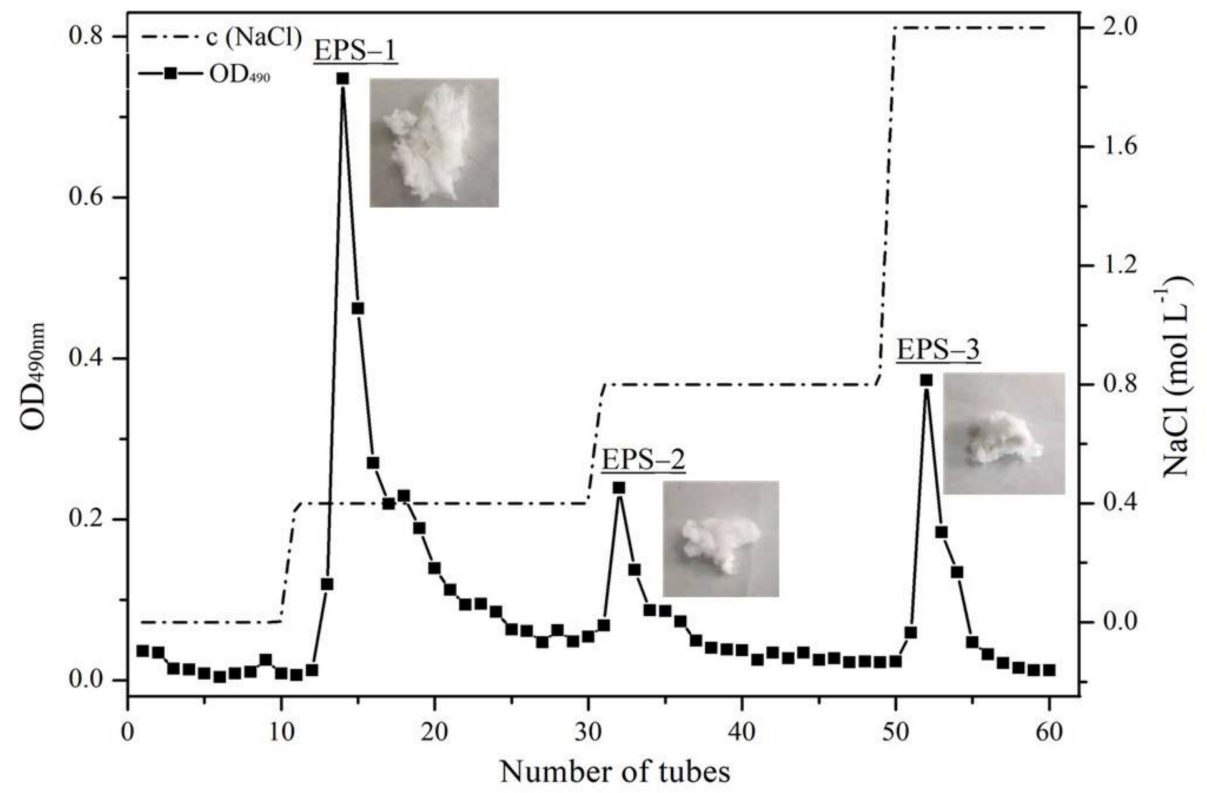

Figure 4. Elution profiles of exopolysaccharides by DEAE-cellulose column chromatography with gradient of $\mathrm{NaCl}$ solution $\left(0,0.4,0.8\right.$, and $\left.2.0 \mathrm{~mol} \mathrm{~L}^{-1}\right)$.

Subsequently, the total carbohydrate, protein, and uronic acid content of the three purified polysaccharide fractions were determined (Table 2). The total carbohydrate and protein content of the three fractions were significantly different $(p<0.05)$. Total carbohydrate content of EPS-1, EPS-2, and EPS-3 were 53.27\% DW, 42.36\% DW, and 39.15\% DW, respectively, and the protein content was $0.95 \% \mathrm{DW}, 0.80 \% \mathrm{DW}$, and $0.86 \% \mathrm{DW}$, respectively. Uronic acid content was 7.04\% DW, 6.82\% DW, and 6.56\% DW, respectively, with no significant difference $(p>0.05)$.

Table 2. Chemical composition of purified polysaccharide fractions.

\begin{tabular}{cccc}
\hline Chemical & \multicolumn{3}{c}{ Sample } \\
\cline { 2 - 4 } Composition (\%DW) & EPS-1 & EPS-2 & EPS-3 \\
\hline Total carbohydrate & $53.27 \pm 0.09^{\mathrm{a} 1}$ & $42.36 \pm 0.18^{\mathrm{b} 1}$ & $39.15 \pm 0.17^{\mathrm{c} 1}$ \\
Protein & $0.95 \pm 0.01^{\mathrm{a} 2}$ & $0.80 \pm 0.02^{\mathrm{c} 2}$ & $0.86 \pm 0.01^{\mathrm{b} 2}$ \\
Uronic acid & $7.04 \pm 0.50^{\mathrm{a} 3}$ & $6.82 \pm 0.42^{\mathrm{a} 3}$ & $6.56 \pm 0.39^{\mathrm{a} 3}$ \\
\hline
\end{tabular}

DW: dry weight, EPS: exopolysaccharides. Different letters denoted significant differences among the percentage of different chemical components of EPS-1, EPS-2, and EPS-3 ( ${ }^{\mathrm{a} 1-\mathrm{c1}}$ : Total carbohydrate; ${ }^{\mathrm{a} 2-\mathrm{c} 2}$ : Protein; ${ }^{\text {a3 }}$ : Uronic acid).

\subsection{Primary Structures Characterization of Purified Fractions}

The monosaccharide compositions of EPS-1, EPS-2, and EPS-3 were determined by gas chromatography, and the results are shown in Table 3. The retention time of arabinose, fucose, xylose, mannose, glucose, and galactose was $19.58 \mathrm{~min}, 19.80 \mathrm{~min}, 20.33 \mathrm{~min}$, $27.78 \mathrm{~min}, 28.80 \mathrm{~min}$, and $28.90 \mathrm{~min}$, respectively (Figure 5). The B. braunii SCS-1905 EPS was mainly composed of four monosaccharides, including arabinose, fucose, glucose, and 
galactose, among which the content of galactose is the highest (52.34-54.12\%), followed by glucose (34.60-35.53\%) and arabinose (9.41-10.32\%); fucose content is the lowest, accounting for only about $2 \%$. EPS-1, EPS-2, and EPS-3 showed no significant difference in the percentage content of glucose and fucose $(p>0.05)$, while EPS-3 expressed a remarkable high amount of arabinose and low galactose content $(p<0.05)$.

Table 3. Chemical composition of exopolysaccharides.

\begin{tabular}{cccc}
\hline \multirow{2}{*}{$\begin{array}{c}\text { Percentage (\%Total } \\
\text { Carbohydrate) }\end{array}$} & \multicolumn{3}{c}{ Sample } \\
\cline { 2 - 4 } & EPS-1 & EPS-2 & EPS-3 \\
\hline Galactose & $54.12 \pm 0.19^{\mathrm{a} 1}$ & $53.82 \pm 0.80^{\mathrm{a} 1}$ & $52.34 \pm 0.61^{\mathrm{b} 1}$ \\
Glucose & $34.60 \pm 0.02$ & $34.65 \pm 0.86$ & $35.53 \pm 0.20$ \\
Arabinose & $9.41 \pm 0.09^{\mathrm{b} 2}$ & $9.54 \pm 0.24^{\mathrm{b} 2}$ & $10.32 \pm 0.16^{\mathrm{a} 2}$ \\
Fucose & $1.87 \pm 0.25$ & $1.99 \pm 0.18$ & $1.80 \pm 0.25$ \\
\hline
\end{tabular}

DW: dry weight, EPS: exopolysaccharides. Different letters denoted significant differences among the percentage of different monosaccharide composition of EPS-1, EPS-2, and EPS-3 ( ${ }^{\mathrm{a} 1-\mathrm{b} 1}$ : galactose; ${ }^{\mathrm{a} 2 \mathrm{~b} 2}{ }^{\text {: }}$ arabinose).

The Fourier-transform infrared absorption (FT-IR) spectra of three purified fractions within the range of $4000-400 \mathrm{~cm}^{-1}$ are depicted in Figure 6 . The infrared peaks were assigned according to the existing literature. The broad absorption peaks at $3326-3338 \mathrm{~cm}^{-1}$ were the stretching vibrations of hydroxyl $(-\mathrm{OH})$; the weak absorption peaks at $2925-2931 \mathrm{~cm}^{-1}$ may be related to the stretching vibration of the $\mathrm{C}-\mathrm{H}$ bond on the sugar ring [28]. The above two bonds are typical infrared absorption peaks of polysaccharides. The absorption peaks that appeared at $1612 \mathrm{~cm}^{-1}$ were derived from the stretching vibration of the $-\mathrm{CHO}$ and $-\mathrm{C}=\mathrm{O}$ bond of the $-\mathrm{COOH}$ group in uronic acid [29]. Protein characteristic absorption at $1411 \mathrm{~cm}^{-1}$ indicated the presence of small amounts of protein [30]. The absorption peaks appearing at $1244 \mathrm{~cm}^{-1}$ (EPS-1), $1238 \mathrm{~cm}^{-1}$ (EPS-2), $1246 \mathrm{~cm}^{-1}$ (EPS-3), and $1023 \mathrm{~cm}^{-1}$ (EPS-1), $1035 \mathrm{~cm}^{-1}$ (EPS-2), $1026 \mathrm{~cm}^{-1}$ (EPS-3) corresponded to the stretching vibration of the $\mathrm{C}-\mathrm{O}$ bond in $\mathrm{C}-\mathrm{OH}$ and $\mathrm{C}-\mathrm{O}-\mathrm{C}$ [31]. The absorption bands at $1149 \mathrm{~cm}^{-1}$ (EPS-1), $1147 \mathrm{~cm}^{-1}$ (EPS-2), and $1155 \mathrm{~cm}^{-1}$ (EPS-3) represented the presence of $\beta$-glycosidic bonds. The absorption bands at $853 \mathrm{~cm}^{-1}$ (EPS-1), $856 \mathrm{~cm}^{-1}$ (EPS-2), and $864 \mathrm{~cm}^{-1}$ (EPS-3) were generally caused by the vibration of a pyranose ring with a glycosidic bond type of $\beta$-configuration [30]. The infrared spectroscopy results showed that EPS-1, EPS-2, and EPS-3 all have typical absorption peaks of polysaccharide, and there was a pyranose ring with a glycosidic bond type of $\beta$-configuration [32].

\subsection{Evaluation of Antioxidant Activity}

The antioxidant activity of B. braunii EPS was evaluated by measuring the scavenging activity against four free radicals (ABTS, hydroxyl, Superoxide anion, and DPPH radical), and the results are shown in Figure 7. Due to the low polarity requirement of the sample, ABTS is extensively utilized as a non-physiological free radical in in vitro antioxidant assays. Figure 7a showed the scavenging activities of CEPS and DEPS against ABTS radicals. When the concentration was in the range of $1.0-5.0 \mathrm{mg} \mathrm{mL}^{-1}$, the scavenging rate of ABTS by CEPS and DEPS increased in a dose-dependent manner, and the maximum scavenging activity reached $48.93 \%$ and $25.51 \%$ when the concentration was $5.0 \mathrm{mg} \mathrm{mL}^{-1}$, respectively, with CEPS significantly higher than DEPS $(p<0.05)$. The $\mathrm{IC}_{50}$ of the samples against ABTS radicals were calculated using GraphPad Prism 7 software and were $5.12 \mathrm{mg} \mathrm{mL}^{-1}$ and $12.38 \mathrm{mg} \mathrm{mL}^{-1}$ for CEPS and DEPS, respectively (Table 4).

The hydroxyl radical scavenging ability of CEPS and DEPS ranging from $1.0-5.0 \mathrm{mg} \mathrm{mL}^{-1}$ concentrations are depicted in Figure $7 \mathrm{~b}$. The maximum scavenging activities of CEPS and DEPS were $99.50 \%$ and $71.15 \%$, respectively, corresponding to $\mathrm{IC}_{50}$ of $1.67 \mathrm{mg} \mathrm{mL} \mathrm{md}^{-1}$ and $3.04 \mathrm{mg} \mathrm{mL}^{-1}$ (Table 4). The scavenging activity of CEPS was up to $99.50 \%$ at $5 \mathrm{mg} \mathrm{mL}^{-1}$, the same as ascorbic acid. Compared with ABTS free radicals, B. braunii EPS had significant hydroxyl radicals scavenging activity. 

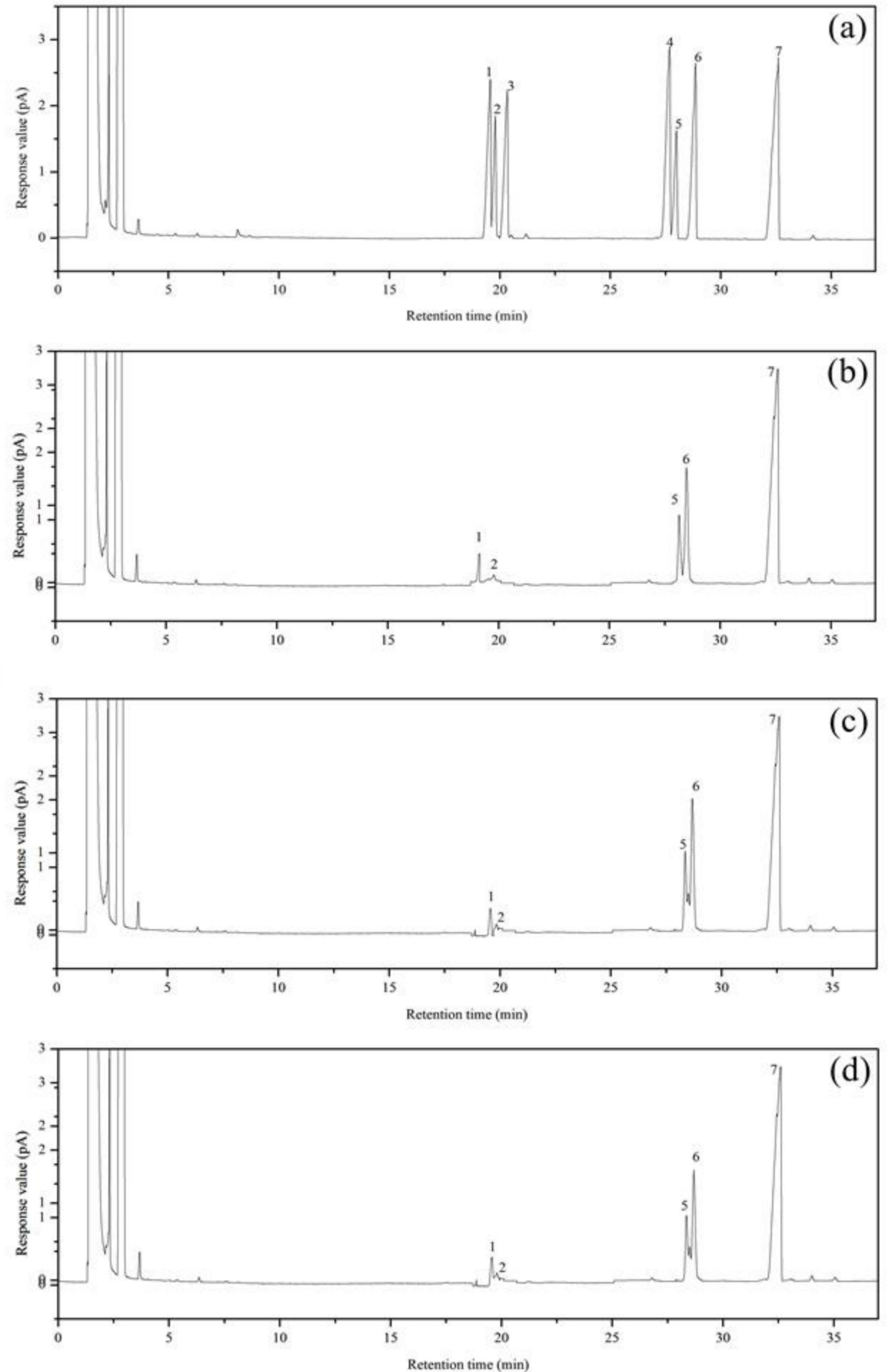

Figure 5. Gas chromatography profiles of (a) mixed standard monosaccharides, (b) EPS-1, (c) EPS-2, and (d) EPS-3. The peaks in chromatography profile (a) from left to right order are as follows: (1) arabinose; (2) fucose; (3) xylose; (4) mannose; (5) glucose; (6) galactose; (7) inositol. EPS: exopolysaccharides.

DPPH is a non-physiological free radical that is employed to assess the antioxidant capacity of active compounds that are soluble in polar reagents, such as lipids and phenols. DPPH radical scavenging activity of CEPS and DEPS with the concentrations ranging from 0.2 to $1.0 \mathrm{mg} \mathrm{L}^{-1}$ were depicted in Figure 7c. Neither CEPS nor DEPS showed concentration-dependent DPPH radical scavenging activity that concluded the two had no DPPH scavenging activity. This might be due to the fact that polysaccharides are insoluble in ethanol and the contact of polysaccharide with the DPPH reagents would produce insoluble substances and appear turbid, making the absorbance value readings more incorrect.

The superoxide anion radical scavenging activities of CEPS and DEPS were exhibited in Figure 7d. Superoxide anion radicals scavenging activities of both CEPS and DEPS did 
not show concentration dependence at the concentration range of $1.0-5.0 \mathrm{mg} \mathrm{mL}^{-1}$, hence both were considered to have no $\mathrm{O}_{2}{ }^{-}$scavenging activity.

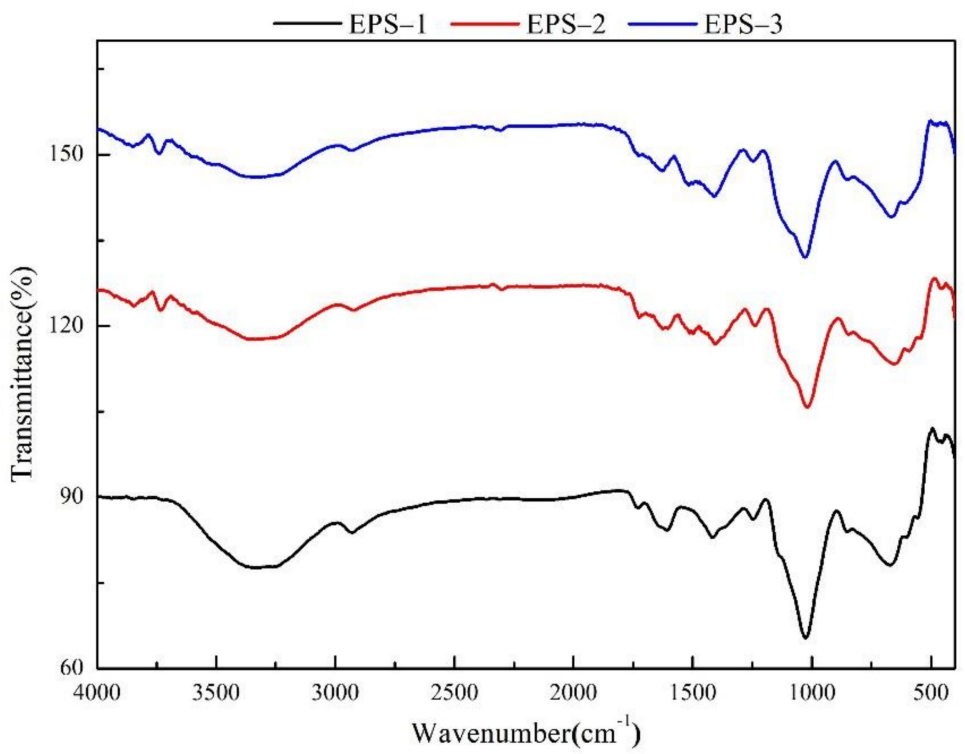

Figure 6. Fourier-transform infrared absorption spectra of purified fractions, EPS: exopolysaccharides.
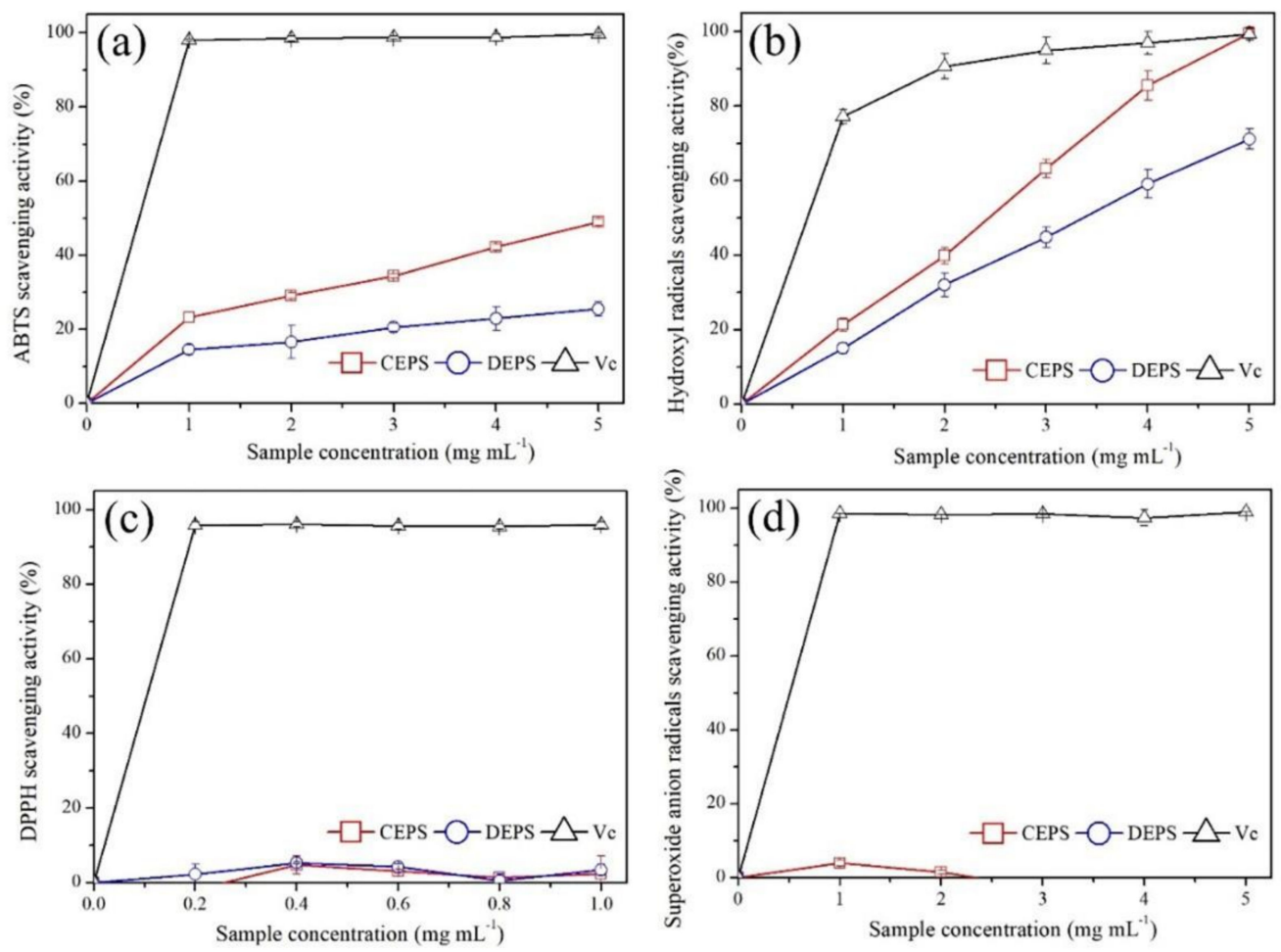

Figure 7. Radical-scavenging activity of crude exopolysaccharides and deproteinized exopolysaccharides. (a) ABTS, (b) hydroxyl radicals, (c) DPPH, and (d) superoxide anion radicals. CEPS: crude exopolysaccharides, DEPS: deproteinized exopolysaccharides, Vc: Ascorbic acid. ( $\mathrm{n}=3$; data: mean $\pm \mathrm{SD})$. 
Table 4. $\mathrm{IC}_{50}$ of crude exopolysaccharides and deproteinized exopolysaccharides.

\begin{tabular}{cccc}
\hline \multirow{2}{*}{$\mathbf{I C}_{\mathbf{5 0}}\left(\mathbf{m g} \cdot \mathbf{m L}^{-\mathbf{1}}\right)$} & \multicolumn{3}{c}{ Sample } \\
\cline { 2 - 4 } & CEPS & DEPS & Vc \\
\hline ABTS & $5.13 \pm 0.11^{\mathrm{b} 1}$ & $12.38 \pm 1.06^{\mathrm{a} 1}$ & $0.003 \pm 0.001^{\mathrm{c} 1}$ \\
OH. & $1.67 \pm 0.06^{\mathrm{b} 2}$ & $3.04 \pm 0.30^{\mathrm{a} 2}$ & $0.240 \pm 0.001^{\mathrm{c} 2}$ \\
\hline
\end{tabular}

DW: dry weight, CEPS: crude exopolysaccharides, DEPS: deproteinized exopolysaccharides, Vc: Ascorbic acid ABTS: 2, 2'-azinobis (3-ethylbenzothiazoline-6-sulfonic acid, OH: hydroxyl radical, $\mathrm{IC}_{50}$ : half maximal inhibitory concentration. Different letters denote significant differences among the values of $\mathrm{IC}_{50}$ of different free radicals scavenging activity of CEPS and DEPS ( ${ }^{\mathrm{a}-\mathrm{c} 1}$ : ABTS; $\left.{ }^{\mathrm{a} 2-\mathrm{c} 2} \mathrm{OH} \cdot \mathrm{O}\right)$.

In conclusion, B. braunii EPS exhibits antioxidant activity against various radicals in vitro, but was not very potent, as evidenced by its lack of scavenging ability against DPPH and superoxide anion radicals. The activity of CEPS was significantly higher than DEPS, and the antioxidant capacity of both was mainly shown by the scavenging ability of hydroxyl radicals.

\section{Discussion}

Based on morphological and molecular identification, it was concluded that the microalga strain SCS-1905 belonged to Chlorophyta, Trebouxiophyceae, Trebouxiales, Botryococcaceae, Botryococcus, Botryococcus braunii, and showed a close phylogenetic relationship with B. braunii AC768. Accordingly, it was classified as race L [33]. Previous studies mostly focused on the excellent hydrocarbon production properties and were committed to its development and application as a source of biofuels, due to the excellent performance in synthesizing and accumulating various lipids and hydrocarbons [34]. Not only that, B. braunii could secrete large amounts of polysaccharides into the surroundings, with the production up to $5.0 \mathrm{~g} \mathrm{~L}^{-1}$ [35]. Because of its remarkable exopolysaccharide synthesis capabilities, $B$. braunii seems to be a promising candidate for microalgal EPS industrialization. Although some studies have investigated the factors that affect B. braunii EPS secretion and outdoor cultivation, the physicochemical and structural properties, as well as biological activity, have not been documented in detail. In this study, we isolated a new strain of B. braunii and purified the EPS, focusing on the composition and antioxidant activities in vitro.

The chemical composition and structure of B. braunii SCS-1905 EPS have been characterized. The results of infrared spectroscopy $\left(1411 \mathrm{~cm}^{-1}\right)$ and protein content determination by the Lowry method $(2.3 \% \mathrm{DW})$ confirmed that proteins were still present in the polysaccharides after the Sevage method treatment, implying that the exopolysaccharide of $B$. braunii may be a proteoglycan [36,37]. Allard and Casadevall (1990) reported the existence of proteins in EPS of race $\mathrm{A}, \mathrm{B}$, and $\mathrm{L}$ in the range of $5-10 \% \mathrm{DW}$, which is consistent with our findings [17]. To date, the structural analysis of B. braunii EPS has not been extensively studied, and chemical methods alone are not enough to determine that it is a proteoglycan. The first structural characterization of race B EPS was recently carried out, demonstrating that the B. braunii polysaccharide is composed of a 3-linked $\alpha$-Galp backbone, with 4-O-methyl-D-glucopyranuronic acid and D-galactopyranose (6-deoxyaltropyranose and 6-deoxyaltrofuranose as terminal residues) [38]. Nevertheless, the monosaccharide composition and ratios of the four races of $B$. braunii vary greatly among each other, and therefore are not universal and do not provide a generalized and comprehensive description of the structural features In addition to excreting polysaccharides to the surrounding environment, the polysaccharide fibrillar sheath in the cell wall is also one of the sources of EPS [15]. Since the daughter cells of B. braunii will detach from the mother cell to form a new colony, the polysaccharide sheath of the mother cell will fall off and free in the medium during this process. Tatli et al., (2018) analyzed the morphology and structural components of the complex extracellular matrix of B. braunii and found that the colony was coated with arabinose (46.7\%) and galactose (36.3\%) [39]. In the formed polysaccharide fibrillar sheath, the protein content accounted for about $1.25 \%$, which might be connected to the 
fibrillar formation. Subsequent studies showed that the polysaccharide associated protein was a unique extracellular matrix hydroxyproline-rich glycoprotein that involved ECM polysaccharide fiber biosynthesis [40]. Since the composition of the polysaccharide sheath shed from the top of the cell during the process of cell division had merely been determined, it was impossible to confirm whether the B. braunii EPS was exclusively composed of the proteoglycan.

The purified polysaccharide fractions EPS-1, EPS-2, and EPS-3 were obtained by elution with different concentrations of $\mathrm{NaCl}$ solution, and the monosaccharide composition and infrared spectra showed no significant difference. The results of infrared spectroscopy showed that B. braunii SCS-1905 EPS had typical absorption peaks of polysaccharides and contained uronic acid. Due to the excellent ability to chelate metal ions, polysaccharides containing uronic acid groups could be useful as sewage treatment agents and heavy metal antidotes [41,42]. B. braunii SCS-1905 EPS was mainly composed of galactose, glucose, arabinose and a small amount of fucose. Our results were consistent with previous studies. Metzger and Largeau (2005) analyzed the exopolysaccharides of 16 different strains of B. braunii and found that galactose was the primary monosaccharide in 10 of them, while glucose was the main monosaccharide in the other six [33]. Allard and Casadevall (1990) also identified several uncommon O-methylated sugars, including 3-O-methylrhamnose, 3-O-methylfucose and 6-O-methylhexose [17]. Galactose, the main scaffold present in the exopolysaccharide fraction, is an interesting monosaccharide for the chemical industry as bioethanol and for the food industry as a prebiotic [43,44]. Moreover, B. braunii EPS could be a source of fucose, a 6-deoxy sugar that was a valuable substrate in the chemical production of flavoring compounds [35].

Microalgal EPS are widely acknowledged for a variety of excellent biological activities, such as antioxidant, anti-tumor, antibacterial and immune activity, while the biological activity of B. braunii EPS has not been reported [45-48]. The various biological activities of natural polysaccharides are the result of a complex interaction of diverse structural features, including molecular weight, monosaccharide composition, degree of sulfation and sulfation position, protein content and stereochemical features [48]. For instance, the anticoagulant activity of fuciodan is determined by a combination of their monosaccharide composition, molecular weight, degree of sulfation and sulfation position. Harden et al., (2009) demonstrated that galactans, fucans and galactofucans with different structures, sulfation patterns, and molecular weights all inhibited herpes simplex virus type I and II (HSV) [49]. In contrast, Fernandez et al., (2010) found that the degree of branching of polysaccharides significantly increased their biological activity and that branched fucoidan oligosaccharides had higher anti-inflammatory activity than straight-chain oligosaccharides [50]. The structure-activity relationships of microalgal EPS have not been adequately studied. In this study, the scavenging activities of B. braunii EPS against four free radicals in vitro were evaluated to provide references for the subsequent development and utilization. The strain B. braunii SCS-1905 isolated in this study showed strong hydroxyl radical scavenging activity $\left(\mathrm{IC}_{50}=1.67 \mathrm{mg} \mathrm{mL}^{-1}\right)$. Hydroxyl radicals possessed the strongest oxidation ability among the reactive oxygen radicals, resulting in excessive carbohydrate peroxidation, amino acids, proteins, nucleic acids, and other molecules [25]. Previous studies showed that the carboxyl group in the uronic acid group could reduce the formation of hydroxyl radicals by chelating metal ions [51]. Therefore, the strong antioxidant activity of $B$. braunii SCS-1905 EPS might be due to the uronic acid group chelating $\mathrm{Fe}^{2+}$ to reduce the generation of hydroxyl free radicals. However, the same strong antioxidant capacity was not observed in the scavenging assay of ABTS. The EPS had relatively poor scavenging capacity for ABTS, and the scavenging activity was only $25.51 \%$ when the polysaccharide concentration was $5.0 \mathrm{mg} \mathrm{mL}^{-1}$. Despite the fact that the ABTS assay employed non-physiological free radicals, it may indicate whether a compound may directly scavenge free radicals [52]. The elimination of ABTS free radicals was caused by the electron transfer reaction of antioxidants, and sulfate acid groups were generally used as electron donors in polysaccharides [53]. The results of Liu et al., (2016) on antioxidant activity of Flammulina velutipes 
polysaccharides, suggesting higher acidic polysaccharide contents led to stronger ABTS scavenging activity [54]. In previous studies, no sulfate groups were found in B. braunii EPS, while in this study, B. braunii SCS-1905 EPS was detected with trace sulfate content (less than $2 \%$ DW), so the weak scavenging activity of EPS against ABTS from B. braunii might be caused by its low sulfate content $[17,55]$. The study into the antioxidant activity of sulfated polysaccharide fractions from Porphyra haitanesis has demonstrated that the sulfate content was not the only factor that influences the antioxidant activity, which is also affected by protein content. The higher the protein content, the stronger the antioxidant activity [56].

\section{Conclusions}

The newly isolated Botryococcus braunii SCS-1905 was identified as belonging to the chemical race L of B. braunii, with the potential to produce EPS. B. braunii SCS-1905 EPS were macromolecular polysaccharides containing uronic acid, protein and a low content of sulfuric acid groups. The monosaccharide composition included galactose, glucose, arabinose and fucose, and there were pyranose rings with a glycosidic bond type of $\beta$-configuration. Moreover, B. braunii SCS-1905 EPS indicated a considerable hydroxyl radical scavenging activity. Therefore, $B$. braunii could be regarded as a promising alternative strain of microalgal EPS applied in the pharmaceutical, nutraceutical, and cosmeceutical industries as an alternative polysaccharide source.

Author Contributions: Conceptualization, W.-N.W. and T.L.; methodology, T.L.; formal analysis, W.-N.W.; resources, T.L.; investigation, W.-N.W. and Y.L.; writing-original draft preparation, T.L. and W.-N.W.; writing-review and editing, H.-L.W., Y.Z. and W.-Z.X.; supervision, W.-Z.X. and A.-F.L.; funding acquisition, W.-Z.X. All authors have read and agreed to the published version of the manuscript.

Funding: This work was supported by the Key Special Project for Introduced Talents Team of Southern Marine Science and Engineering Guangdong Laboratory (Guangzhou) (No. GML2019ZD0406), Engineering Research Center for Tropical and Subtropical Aquatic Ecological Engineering, Ministry of Education, Jinan University, P.R. China (No. 2021B0402), the Key-Area Research and Development Program of Guangdong Province (No. 2020B1111030004), and Guangdong Provincial Key Laboratory of New and Renewable Energy Research and Development (No. E039kf0301).

Institutional Review Board Statement: The study did not involve humans or animals.

Informed Consent Statement: The study did not involve humans or animals.

Data Availability Statement: No new data were created or analyzed in this study. Data sharing is not applicable to this article.

Conflicts of Interest: The authors declare no conflict of interest.

\section{References}

1. Xiao, R.; Zheng, Y. Overview of microalgal extracellular polymeric substances (EPS) and their applications. Biotechnol. Adv. 2016, 34, 1225-1244. [CrossRef] [PubMed]

2. De Philippis, R.; Sili, C.; Paperi, R.; Vincenzini, M. Exopolysaccharide-producing cyanobacteria and their possible exploitation: A review. J. Appl. Phycol. 2001, 13, 293-299. [CrossRef]

3. Mann, E.E.; Wozniak, D.J. Pseudomonas biofilm matrix composition and niche biology. FEMS Microbiol. Rev. 2012, 36, 893-916. [CrossRef] [PubMed]

4. Yalcin, I.; Hicsasmaz, Z.; Boz, B.; Bozoglu, F. Characterization of the extracellular polysaccharide from freshwater microalgae Chlorella sp. LWT-Food Sci. Technol. 1994, 27, 158-165. [CrossRef]

5. Arad, S.; Rapoport, L.; Moshkovich, A.; van Moppes, D.; Karpasas, M.; Golan, R.; Golan, Y. Superior biolubricant from a species of red microalga. Langmuir 2006, 22, 7313-7317. [CrossRef]

6. De Jesus Raposo, M.F.; de Morais, A.M.; de Morais, R.M. Emergent sources of prebiotics: Seaweeds and microalgae. Mar. Drugs 2016, 14, 27. [CrossRef]

7. Sun, L.; Wang, C.; Shi, Q.; Ma, C. Preparation of different molecular weight polysaccharides from Porphyridium cruentum and their antioxidant activities. Int. J. Biol. Macromol. 2009, 45, 42-47. [CrossRef]

8. De Jesus Raposo, M.F.; de Morais, A.M.; de Morais, R.M. Influence of sulphate on the composition and antibacterial and antiviral properties of the exopolysaccharide from Porphyridium cruentum. Life Sci. 2014, 101, 56-63. [CrossRef] 
9. Guzman, S.; Gato, A.; Lamela, M.; Freire-Garabal, M.; Calleja, J. Anti-inflammatory and immunomodulatory activities of polysaccharide from Chlorella stigmatophora and Phaeodactylum tricornutum. Phytother. Res. 2003, 17, 665-670. [CrossRef]

10. Zheng, W.; Chen, C.; Cheng, Q.; Wang, Y.; Chu, C. Oral administration of exopolysaccharide from Aphanothece halophytica (Chroococcales) significantly inhibits influenza virus (H1N1)-induced pneumonia in mice. Int. Immunopharmacol. 2006, 6, 1093-1099. [CrossRef]

11. Senousy, H.H.; Beakes, G.W.; Hack, E. Phylogenetic placement of Botryococcus braunii (Trebouxiophyceae) and Botryococcus sudeticus isolate UTEX 2629 (Chlorophyceae). J. Appl. Phycol. 2004, 40, 412-423. [CrossRef]

12. Metzger, P.; Berkaloff, C.; Casadevall, E.; Coute, A. Alkadiene-and botryococcene-producing races of wild strains of Botryococcus braunii. Phytochemistry 1985, 24, 2305-2312. [CrossRef]

13. Metzger, P.; Allard, B.; Casadevall, E.; Berkaloff, C.; Couté, A. Structure and chemistry of a new chemical race of Botryococcus braunii (Chlorophyceae) that produces lycopadiene, a tetraterpenoid hydrocarbon. J. Appl. Phycol. 1990, 26, 258-266. [CrossRef]

14. Kawachi, M.; Tanoi, T.; Demura, M.; Kaya, K.; Watanabe, M.M. Relationship between hydrocarbons and molecular phylogeny of Botryococcus braunii. Algal Res. 2012, 1, 114-119. [CrossRef]

15. Casadevall, E.; Dif, D.; Largeau, C.; Gudin, C.; Chaumont, D.; Desanti, O. Studies on batch and continuous cultures of Botryococcus braunii: Hydrocarbon production in relation to physiological state, cell ultrastructure, and phosphate nutrition. Biotechnol. Bioeng. 1985, 27, 286-295. [CrossRef]

16. Fernandes, H.; Tomé, M.; Lupi, F.; Fialho, A.; Sá-Correia, I.; Novais, J. Biosynthesis of high concentrations of an exopolysaccharide during the cultivation of the microalga Botryococcus braunii. Biotechnol. Lett. 1989, 11, 433-436. [CrossRef]

17. Allard, B.; Casadevall, E. Carbohydrate composition and characterization of sugars from the green microalga Botryococcus braunii. Phytochemistry 1990, 29, 1875-1878. [CrossRef]

18. Li, T.; Xu, J.; Gao, B.; Xiang, W.; Li, A.; Zhang, C. Morphology, growth, biochemical composition and photosynthetic performance of Chlorella vulgaris (Trebouxiophyceae) under low and high nitrogen supplies. Algal Res. 2016, 16, 481-491. [CrossRef]

19. Chen, Z.; Lei, X.; Zhang, B.; Yang, L.; Zhang, H.; Zhang, J.; Li, Y.; Zheng, W.; Tian, Y.; Liu, J. First report of Pseudobodo sp., a new pathogen for a potential energy-producing algae: Chlorella vulgaris cultures. PLoS ONE 2014, 9, e89571. [CrossRef]

20. Dubois, M.; Gilles, K.A.; Hamilton, J.K.; Rebers, P.T.; Smith, F. Colorimetric method for determination of sugars and related substances. Anal. Chem. 1956, 28, 350-356. [CrossRef]

21. Lowry, O.H.; Rosebrough, N.J.; Farr, A.L.; Randall, R.J. Protein measurement with the folin phenol reagent. J. Biol. Chem. 1951, 193, 265-275. [CrossRef]

22. Blumenkrantz, N.; Asboe-Hansen, G. New method for quantitative determination of uronic acids. Anal. Chem. 1973, 54, 484-489. [CrossRef]

23. Reim, R.E. Total sulfite in cellulosics by ion exclusion chromatography with electrochemical detection. J. Food. Sci. 1991, 56, 1079-1090. [CrossRef]

24. Luo, J.; Liu, J.; Sun, Y.; Ye, H.; Zhou, C.; Zeng, X. Medium optimization, preliminary characterization and antioxidant activity in vivo of mycelial polysaccharide from Phellinus baumii Pilát. Carbohydr. Polym. 2010, 81, 533-540. [CrossRef]

25. Li, X.; Lin, J.; Gao, Y.; Han, W.; Chen, D. Antioxidant activity and mechanism of Rhizoma Cimicifugae. Chem. Cent. J. 2012, 6, 140. [CrossRef]

26. Li, Y.; Jiang, B.; Zhang, T.; Mu, W.; Liu, J. Antioxidant and free radical-scavenging activities of chickpea protein hydrolysate (CPH). Food Chem. 2008, 106, 444-450. [CrossRef]

27. Chen, Y.; Liu, X.; Wu, L.; Tong, A.; Zhao, L.; Liu, B.; Zhao, C. Physicochemical characterization of polysaccharides from Chlorella pyrenoidosa and its anti-ageing effects in Drosophila melanogaster. Carbohydr. Polym. 2018, 185, 120-126. [CrossRef]

28. Wu, M.; Feng, H.; Song, J.; Chen, L.; Xu, Z.; Xia, W.; Zhang, W. Structural elucidation and immunomodulatory activity of a neutral polysaccharide from the Kushui Rose (Rosa setate x Rosa rugosa) waste. Carbohydr. Polym. 2020, 232, 115804. [CrossRef]

29. Wang, B. Chemical characterization and ameliorating effect of polysaccharide from Chinese jujube on intestine oxidative injury by ischemia and reperfusion. Int. J. Biol. Macromol. 2011, 48, 386-391. [CrossRef]

30. Kozarski, M.; Klaus, A.; Nikšić, M.; Vrvić, M.M.; Todorović, N.; Jakovljević, D.; Van Griensven, L.J. Antioxidative activities and chemical characterization of polysaccharide extracts from the widely used mushrooms Ganoderma applanatum, Ganoderma lucidum, Lentinus edodes and Trametes versicolor. J. Food Compost. Anal. 2012, 26, 144-153. [CrossRef]

31. Kacurakova, M.; Capek, P.; Sasinkova, V.; Wellner, N.; Ebringerova, A. FT-IR study of plant cell wall model compounds: Pectic polysaccharides and hemicelluloses. Carbohydr. Polym. 2000, 43, 195-203. [CrossRef]

32. Liu, C.H.; Wang, C.H.; Xu, Z.L.; Wang, Y. Isolation, chemical characterization and antioxidant activities of two polysaccharides from the gel and the skin of Aloe barbadensis Miller irrigated with sea water. Process Biochem. 2007, 42, 961-970.

33. Gouveia, J.D.; Ruiz, J.; van den Broek, L.A.; Hesselink, T.; Peters, S.; Kleinegris, D.M.; Smith, A.G.; van der Veen, D.; Barbosa, M.J.; Wijffels, R.H. Botryococcus braunii strains compared for biomass productivity, hydrocarbon and carbohydrate content. J. Biotechnol. 2017, 248, 77-86. [CrossRef] [PubMed]

34. Metzger, P.; Largeau, C. Botryococcus braunii: A rich source for hydrocarbons and related ether lipids. Appl. Microbiol. Biotechnol. 2005, 66, 486-496. [CrossRef]

35. Lupi, F.M.; Fernandes, H.M.; Sá-Correia, I.; Novais, J.M. Temperature profiles of cellular growth and exopolysaccharide synthesis by Botryococus braunii Kütz. UC 58. J. Appl. Phycol. 1991, 3, 35-42. [CrossRef] 
36. Chiovitti, A.; Harper, R.E.; Willis, A.; Bacic, A.; Mulvaney, P.; Wetherbee, R. Variations in the substituted 3-linked mannans closely associated with the silicified walls of diatoms. J. Appl. Phycol. 2005, 41, 1154-1161. [CrossRef]

37. Wang, W.N.; Li, Y.; Zhang, Y.; Xiang, W.Z.; Li, A.F.; Li, T. Comparison on characterization and antioxidant activity of exopolysaccharides from two Porphyridium strains. Appl. Phycol. 2021, 33, 2983-2994. [CrossRef]

38. Heiss, C.; Black, I.; Ishihara, M.; Tatli, M.; Devarenne, T.P.; Azadi, P. Structure of the polysaccharide sheath from the B race of the green microalga Botryococcus braunii. Algal Res. 2021, 55, 102252. [CrossRef]

39. Weiss, T.L.; Roth, R.; Goodson, C.; Vitha, S.; Black, I.; Azadi, P.; Rusch, J.; Holzenburg, A.; Devarenne, T.P.; Goodenough, U. Colony organization in the green alga Botryococcus braunii (Race B) is specified by a complex extracellular matrix. Eukaryot. Cell 2012, 11, 1424-1440. [CrossRef]

40. Tatli, M.; Ishihara, M.; Heiss, C.; Browne, D.R.; Dangott, L.J.; Vitha, S.; Azadi, P.; Devarenne, T.P. Polysaccharide associated protein (PSAP) from the green microalga Botryococcus braunii is a unique extracellular matrix hydroxyproline-rich glycoprotein. Algal Res. 2018, 29, 92-103. [CrossRef]

41. Banerjee, A.; Sharma, R.; Chisti, Y.; Banerjee, U. Botryococcus braunii: A renewable source of hydrocarbons and other chemicals. Crit. Rev. Biotechnol. 2002, 22, 245-279. [CrossRef]

42. Kaplan, D.; Christiaen, D.; Arad, S.M. Chelating properties of extracellular polysaccharides from Chlorella spp. Appl. Environ. Microbiol. 1987, 53, 2953-2956. [CrossRef]

43. Lee, K.S.; Hong, M.E.; Jung, S.C.; Ha, S.J.; Yu, B.J.; Koo, H.M.; Park, S.M.; Seo, J.H.; Kweon, D.H.; Park, J.C. Improved galactose fermentation of Saccharomyces cerevisiae through inverse metabolic engineering. Biotechnol. Bioeng. 2011, 108, 621-631. [CrossRef]

44. García-Cubero, R.; Cabanelas, I.T.; Sijtsma, L.; Kleinegris, D.M.; Barbosa, M.J. Production of exopolysaccharide by Botryococcus braunii CCALA 778 under laboratory simulated Mediterranean climate conditions. Algal Res. 2018, 29, 330-336. [CrossRef]

45. Zhang, J.; Liu, L.; Chen, F. Production and characterization of exopolysaccharides from Chlorella zofingiensis and Chlorella vulgaris with anti-colorectal cancer activity. Int. J. Biol. Macromol. 2019, 134, 976-983. [CrossRef]

46. Fritzsche, S.; Blenk, P.; Christian, J.; Castiglione, K.; Becker, A.M. Inhibitory properties of crude microalgal extracts on the in vitro replication of cyprinid herpesvirus 3. Sci. Rep. 2021, 11, 23134. [CrossRef]

47. Guzman-Murillo, M.; Ascencio, F. Anti-adhesive activity of sulphated exopolysaccharides of microalgae on attachment of red sore disease-associated bacteria and Helicobacter pylori to tissue culture cells. Lett. Appl. Microbiol. 2000, 30, 473-478. [CrossRef]

48. Fujitani, N.; Sakaki, S.; Yamaguchi, Y.; Takenaka, H. Inhibitory effects of microalgae on the activation of hyaluronidase. J. Appl. Phycol. 2001, 13, 489-492. [CrossRef]

49. Jin, J.-O.; Chauhan, P.S.; Arukha, A.P.; Chavda, V.; Dubey, A.; Yadav, D. The therapeutic potential of the anticancer activity of fucoidan: Current advances and hurdles. Mar. Drugs 2021, 19, 265. [CrossRef]

50. Fernandez, O.; Béthencourt, L.; Quero, A.; Sangwan, R.S.; Clément, C. Trehalose and plant stress responses: Friend or foe? Trends Plant Sci. 2010, 15, 409-417. [CrossRef]

51. Shen, S.; Jia, S.; Wu, Y.; Yan, R.; Lin, Y.; Zhao, D.; Han, P. Effect of culture conditions on the physicochemical properties and antioxidant activities of polysaccharides from Nostoc flagelliforme. Carbohydr. Polym. 2018, 198, 426-433. [CrossRef]

52. Floegel, A.; Kim, D.O.; Chung, S.J.; Koo, S.I.; Chun, O.K. Comparison of ABTS/DPPH assays to measure antioxidant capacity in popular antioxidant-rich US foods. J. Food Compost. Anal. 2011, 24, 1043-1048. [CrossRef]

53. Dudonne, S.; Vitrac, X.; Coutiere, P.; Woillez, M.; Mérillon, J.M. Comparative study of antioxidant properties and total phenolic content of 30 plant extracts of industrial interest using DPPH, ABTS, FRAP, SOD, and ORAC assays. J. Agric. Food Chem. 2009, 57, 1768-1774. [CrossRef]

54. Liu, Y.; Zhang, B.; Ibrahim, S.; Gao, S.S.; Yang, H.; Huang, W. Purification, characterization and antioxidant activity of polysaccharides from Flammulina velutipes residue. Carbohydr. Polym. 2016, 145, 71-77. [CrossRef]

55. Bayona, K.C.; Garcés, L.A. Effect of different media on exopolysaccharide and biomass production by the green microalga Botryococcus braunii. J. Appl. Phycol. 2014, 26, 2087-2095. [CrossRef]

56. Zhang, Q.; Yu, P.; Li, Z.; Zhang, H.; Xu, Z.; Li, P. Antioxidant activities of sulfated polysaccharide fractions from Porphyra haitanesis. J. Appl. Phycol. 2003, 15, 305-310. [CrossRef] 